\title{
A Critical Discourse Analysis of Russia Today's In-group and Out-group Presentation in the Syrian Crisis News Reports
}

\author{
Omar Ali Wally Atatfa \\ Dept. of English, College of Education for Human Sciences, University of Babylon, \\ Babylon, Iraq \\ Tel: 964-781-613-0785 E-mail: omar.wally@yahoo.com \\ Asst. Prof. Salih Mahdi Adai Al-Mamoory (Ph. D) \\ College of Education for Human Sciences, University of Babylon, Babylon, Iraq \\ Tel: 964-780-142-2127 E-mail: salih_mehdi71@yahoo.com
}

Received: June 5, 2017 Accepted: June 20, 2017 Published: June 23, 2017

doi:10.5296/elr.v3i2.11437ＵRL: http://doi.org/10.5296/elr.v3i2.11437

\begin{abstract}
This paper presents a critical discourse analysis (henceforth, CDA) of the news items which tackled the Syrian crisis in the English-speaking Russian TV channel Russia Today (henceforth, RT). It aims to show the channel's polarization into its in-group and out-group of the reports that focused on the Syrian crisis. To achieve its aim, the study hypothesizes that: 1) RT utilizes discursive strategies in order to positively present its in-group (Russia, the Syrian regime, and its allies) and negatively present the out-group (the USA, Europe, and their allies) and 2) Russia's military involvement in Syria affected the way RT reports its Syrian crisis news. In order to test the two hypotheses, the study analyzes six reports that tackle the Syrian crisis from RT: three reports before and three after the Russian military involvement. After presenting a theoretical background of the field of CDA, the study follows two models by van Dijk, namely, the Ideological Square (1998), and Ideological Discourse Analysis (1995b) to analyze the data.
\end{abstract}

Keywords: CDA, Ideological Square, The Syrian crisis, Russia 


\section{Introduction}

The Syrian crisis started in 2011 as protests which called for the removal of the Syrian government, led by Bashar Al-Assad. Yet, those protests escalated into a conflict between the protestors and the government's official forces. Consequently, it turned into a war between those who wanted the removal of the regime and the regime itself. Later, the two warring sides received support from regional as well as global powers. On September $30^{\text {th }}, 2015$, Russian military forces were sent to Syria in order to participate in the 'war on terrorism' (Al-Jazeera, 2017).

The modern concept of war is not only that in which guns and fighter jets are used. Rather, it is necessary that there is a supportive media. The role of the media is to fuel the public with knowledge which often benefit one side on the account of another. This is the case in the Syrian crisis which has been tackled excessively in the media.

There are a number of significant research studies on CDA, rhetoric and Systemic Functional Linguistics (SFL) aiming to investigate political discourses in other veins and genres as follows. For instance, Ali and Kazemian (2015a, 2015b) have probed a speech by Liaquat Ali Khan titled 'Pakistan and the Modern World' in light of van Dijk's socio-cognitive model to highlight the important aspects of discourse production and comprehension as well as a reading text 'Pakistan Zindabad' to identify problems showing the gap and unawareness on the part of teachers and students regarding the critical discourse of the text in classroom reading context. They are mainly pursued to discover how the language of a politician pursues people in the enactment of power dominance, inequality, and the imposition of an ideology.

In another study, Zhou and Kazemian (2015) have analyzed John F. Kennedy's Inaugural Addres based on Burkean Identification theory to figure out how the speaker has achieved its rhetorical effect, and has discussed how the politician has used the identification strategies to transcend division, gain identification, induce cooperation, and thus, realize their motives.

In some other veins, Kazemian and Hashemi (2014b, 2017) have introduced an integrated approach to analyze political or other discourses in light of on overarching methodological frameworks of Hallidayan grammatical metaphor, Fairclough's perspective on critical discourse analysis and rhetoric. They have analyzed Obama's eight speeches from the point of frequency and functions of Nominalization, Rhetorical strategies, Passivisation and Modality etc. to first manifest the integrated approach practicality and adeptness through analysis; then by virtue of analysis to unveil how language is manipulated and distorted by orators in order to convey seamlessly intended messages and political creeds to the audience.

Surveying the recent annals of literature, some other considerable studies have also investigated various political, advertisement etc. discourses in light of CDA, SFL and Rhetoric to discern multiple strategies exploited by orators and political pundits and how they make the text/talk persuasive, significant, appealing and obscure, and how they convey their intended objectives to the audience (Cap \& Okulska, 2013, Kazemian et al., 2013; Kazemian $\&$ Hashemi, 2014a; Noor et al., 2015 etc.). Prior studies have tended to concentrate on some 
other genres and discourses. This study is unique in the sense that it attempts to bridge the gap among previous studies by analyzing the Russian channel's polarisation between its in-group and out-group in the reports that focus on the Syrian crisis based on van Dijk to models, namely, the Ideological Square (1998), and Ideological Discourse Analysis (1995b).

\section{Critical Discourse Analysis}

This section introduces CDA in terms of its definitions, principles, aims, and the major concepts used.

\subsection{Definitions of $C D A$}

The definitions of CDA range from greatly political which 'explain existing conventions as the outcome of power relations and power struggle' (Fairclough, 1989) to mild which merely provide answers to questions about the relationships between language and society (Rogers 2005).

According to Fairclough (1995), CDA is a type of discourse analysis which seeks to systematically discover the frequently opaque relations of "causality and determination between (a) discursive practices, events and texts, and (b) wider social and cultural structures, relations, and processes' which are molded by associations of power and struggles over power.

However, Wodak (1995) sees CDA as a way of analysing not only opaque relations, but 'opaque as well as transparent structural relationships of dominance, discrimination, power and control' which may be found in language. Wodak (1997) argues that what makes CDA different is its emphasis on '(a) the relationship between language and society, and (b) the relationship between analysis and practices analysed'.

Van Dijk (1998) considers CDA to be a type of research that analyses discourse which mainly focuses on how social power abuse, dominance, and inequality are enacted, reproduced, and resisted by text and talk in sociopolitical contexts. Therefore, its aim is to discover and, ultimately, resists social inequality.

Luke (2002) adds that CDA is not limited to the linguistic analysis. Rather, the linguistic, semiotic and other tools in the microanalysis of texts and the macroanalysis of social formations, institutions and power relations that the texts 'index and construct'.

Accordingly, most definitions of CDA concentrate on the relationship that connects discourse and power (Fairclough \& Wodak, 1997).

\subsection{Principles of $C D A$}

As a paradigm, CDA comprises a number of principles on which CDA analysts depend in their endeavor. Van Dijk (1993: 252) summarises the principles of CDA by saying that 'CDA should deal primarily with the discourse dimensions of power abuse and the injustice and inequality that result from it'. However, Fairclough and Wodak (1997) mention a number of tenets that CDA scholars should take into account: 


\section{I Macrothink}

1) CDA is concerned with social problems.

2) DA interprets and explains the analysed issues.

3) There are ideological implications in discourse.

4) Discourse is a kind of social behaviour.

5) Discourse relates to history.

6) Discourse arranges opinions and communities.

7) Power relations are related to discourse.

8) The relation between society and text is indirect (mediated').

In their part to pinpoint the characteristics of CDA, Jorgensen and Philips (2002) state the following:

1) The social and linguistic structures are somewhat linguistic-discursive. That is to say, the discursive practices shape the social identities and relations, as they are used as social practices.

2) Since discourse is a sort of social practice, it is inevitable that it constitutes and is constituted by other social practices.

3) The social context in which language is used should not be neglected in the process of empirical discourse analysis.

4) Discourse practices make unequal power relations between social groups; therefore, CDA reveals them to the public.

5) The critical nature of CDA maintains that it should uncover the production of unequal power relations and resist it in order to change the taken-for-granted reality.

Wodak and Meyer (2009) mention that CDA is fueled by problems, so it must be eclectic and interdisciplinary. Thus, CDA is interested in deciphering the perplexity of ideologies within discourse by analysing all sorts of data (semiotic, written, verbal, or visual). In this respect, CDA researchers try to maintain and explain their own interests while using their scientific methodologies, as well as marinating their self-reflection during their research process (ibid.).

\subsection{Aims of CDA}

The aim of CDA is to 'offer a different perspective of theorizing analysis and application throughout the whole field' (van Dijk, 1998). In this respect, Wodak and Meyer (2001: 2) state that the aim of CDA is to critically investigate social inequality 'as it is expressed, signalled, constituted, legitimized and so on by language use (or in discourse)'. Therefore, the majority of scholars in CDA follow Habermas's claim that 'language is also a medium of domination and social force. It serves to legitimise relations of organised power' (ibid.).

However, van Dijk (1998) realises that in order to fulfill its aims, CDA needs a number of requirements, such as the following: 
1) It has to be better than other research in order to be accepted.

2) It should concentrate on social problems and political issues, rather than other issues.

3) It should be multidisciplinary in order to be adequate.

4) It should explain, not describe, the discourse structures according to the features of social interaction, particularly, social structure.

5) It should emphasise how discourse structures enact, confirm, legitimate, reproduce or challenge relations of power and dominance in society.

Similarly, Wodak and Meyer (2009) add that CDA should observe and lead the human language and behaviour, since the critical theories provide people with essential knowledge that liberates them from any kind of mastery whatsoever.

\subsection{Major Concepts of CDA}

CDA manifolds a number of essential concepts. Those include concepts such as discourse, power and ideology, racism, bias, etc. Those concepts are dealt with in a large number of publications. For instance, Fairclough (1995) argues that CDA has within its aims the goal of revealing the hidden connections between texts and social processes, such as power and ideologies which average people may not easily detect.

The term 'discourse' has various meanings, according to who is doing the research and the different academic cultures. For instance, 'text' and 'discourse' are recognised as different in the Central European context and in Germany, relating to the tradition in text linguistics and rhetoric. However, 'discourse' refers to both written and spoken texts in the 'English speaking world’ (Wodak \& Meyer, 2009: 5-7).

Fairclough, (1992) argues that the term discourse has many overlapping definition which makes it hard to pinpoint a specific definition for it. Yet he indicates that each social situation has its own type of discourse, like 'newspaper discourse, advertising discourse, medical discourse', and the like (ibid: 3 ). After all, the three main aspects that discourse is concerned with are: "(1) anything beyond the sentence, (2) language use, and (3) a broader range of social practice that includes nonlinguistic and nonspecific instances of language" (Jaworski \& Coupland, 1999; cited in Schiffirin, D., Tannen,, D, \& Hamilton, H., 2001:1).

Regarding power, it is 'a systemic characteristic, a transformative and non-static feature of interaction that is both enacted and contested in every interaction' (Holmes, 2005: 32). Accordingly, there is a consistent relation between language and power (ibid.). Similarly, Thomas (2004) states that language is a fundamental tool which may turn power into virtue, and conformity into obligation. However, CDA does not look at language as powerful in its own right. Rather, $\mathrm{CD}$ analysts argue that those who use the language are powerful. That is why CDA sides with those who are oppressed by such use of power, and analyzes the language of the people who aim to impose their power, ideologies and inequality (Wodak, 2000).

As far as ideology is concerned, a number of scholars tackled this concept, each focusing on a 
certain perspective(s). For example, Thompson (1990) talks about the concepts of ideology and culture, and the associations between them and particular facets of mass communication. He claims that the concept of ideology first appeared in France in the late eighteenth century (ibid.).

As for van Dijk, ideology is not a system of ideas as much as it is 'specific basic frameworks of social cognition with specific social structures and specific cognitive and social functions' (van Dijk, 1995: 21). Moreover, he argues that ideologies are mainly conveyed in discourse and communication, and that also includes non-verbal interaction such as semiotic messages (images, movies, etc.). That is to say, ideologies take the role of the line between the cognitive representations and the fundamental procedures of discourse and action, on the one hand, and the societal situation and benefits of social groups, on the other hand (ibid.).

\section{Model of Analysis}

This section presents the model adopted in the analysis of the data. The analysis is both qualitative and quantitative. The qualitative analysis relies on van Dijk's Ideological Square (1998) which tackles the concept of in-group and out-group presentation, and Ideological Discourse Analysis (1995b) which provides a number of discursive strategies that help to reveal where language is manipulated to serve certain ideas. The quantitative analysis is made by making a word count for the two main characters, namely, the refugees and the US, to find out the variation in news presentation before and after the Russian military involvement.

\subsection{Ideological Square}

In terms of the positive self-presentation and negative other presentation, Van Dijk (1998: 5) emphasizes how access to discourse by the powerful groups may be 'abused' to control people's beliefs. 'Abuse' here is used with 'some ethical standard, such as (just) rules, agreements, laws or human rights principles'. Such inequality leads to present the group to which the dominant speaker belongs in positive terms, and the group of those who contradict our beliefs with negative terms (ibid.: 263). In his words, van Dijk states that:

Models are being expressed and persuasively conveyed that contrast us with THEM, e.g. by emphasizing our tolerance, help or sympathy, and by focusing on negative social or cultural differences, deviance or threats attributed to them. If such polarized models are consistent with negative attitudes or ideologies, they may be used to sustain existing attitudes or form new negative attitudes. (ibid.). This helps sustaining and emphasizing that the out-group has no excuses whatsoever, and that it is 'always like that' and 'we are not used to that' (ibid. 264).

As such, van Dijk's (1998) Ideological Square states the following moves:

1) Emphasize positive information about us.

2) Emphasize negative information about them.

3) Understate positive information about them.

4) Understate negative' information about us. 


\section{Macrothink \\ Education and Linguistics Research \\ ISSN 2377-1356 \\ 2017, Vol. 3, No. 2}

This square plays a significant role in the strategy of positive self-presentation and its matching part negative-other presentation (van Dijk, 1998). Moreover, van Dijk (2002) looks at ideology as the way in which a group of people react towards particular issues; therefore, CDA takes investigating ideologies as one of the most significant targets in analyzing discourse.

\subsection{Ideological Discourse Analysis}

Van Dijk (1995b) indicates that discourse is often full of ideological orientations that are embedded and may not be recognized by ordinary people. Therefore, he proposes a number of strategies that could help in revealing the ideological repercussions of those discourses (ibid.).

1) Negative lexicalization: choosing lexical items which have strong negative meaning in describing the others.

2) Hyperbole: using exaggerated terms to describe an action or an event.

3) Compassion move: sympathizing the helpless victims of the others in order to show that they are brutal.

4) Apparent Altruism move: 'Related to the compassion move, this move is used to emphasize understanding for the position or interests of (some of) the Others' (ibid).

5) Apparent Honesty move: disclaiming any negative statements of the self. This is a well-known move used with phrases such as 'frankly,...' or 'We should not hide the truth, and..' and the like.

6) Negative comparison: to compare the out-group with a recognized negative person or group so as to emphasize the negative features of the others.

7) Generalization: using one person or a small group to be the point of generalization that describes a whole group or category

8) Concretization: to use terms that may be visualized in order to talk about the actions of the others in detail.

9) Alliteration: 'Phonologically based rhetoric is well-known in tabloid headlines and op-articles, and generally serves to emphasize the importance or relevance of the words thus being marked' (ibid.).

10) Warning: to use fearful terms to frighten the in-group from the out-group. Such as the case of using Doomsday scenarios to demonize the others and waken those who do not take things seriously.

11) Norm and value violation: one way in which to show that the Other group is bad is by presenting them as breaking the beliefs and values that human beings hold dear. For example, freedom of expression, human rights, freedom of education, etc. 
12) Presupposition: presupposition means 'a condition which must be satisfied if a particular state of affairs is to obtain, or (in relation to language) what a speaker assumes in saying a particular sentence, as opposed to what is actually asserted' (Crystal, 2008: 384). This semantic device is used as a tool in the process of positive and negative presentation. That is, in asserting that the presented information is known or part of the common sense, thus does not need to be stated (van Dijk, 1995b: 157).

The study combines these two models in order to come up with an eclectic model. The model is divided into two categories. The first category is Positive Self-Presentation which includes discursive strategies like the Compassion move, Apparent Altruism, and Apparent Honesty. The second category is Negative Other-Presentation which includes discursive strategies like Negative Lexicalisation, Hyperbole, Negative Comparison, Generalisation, Concretisation, Warning, Norm and Value Violation, and Presupposition.

\section{Data Analysis}

This section is concerned with the analysis of (6) reports taken from the website of RT. The first (3) reports belong to the period before Russia interfered in Syria, while the second (3) reports belong the period after the Russian involvement.

\subsection{Report 1}

The report's headline is 'UN envoy to Syria tells world to listen to Russia to end civil war'. Thus, the overall meaning of the report suggests that Russia is the righteous side about what happens in Syria and that the others must listen to it.

Regarding Negative Lexicalisation, the repot uses this strategy to emphasize the negative image of the uprising ('The civil war in Syria began in 2011, when the US-backed opposition began an armed rebellion against President Bashar Assad's government during the Arab Spring; While declaring the need to fight ISIS, Washington has continued to demand the overthrow of Assad in favor of "moderate opposition"'). Thus, referring to the protests as 'armed rebellions' puts them in a negative frame, since armed means 'furnished with weapons' and 'an effort to change a government with violence, and refusal to obey rules or accept normal standards of behaviour'. Moreover, referring to Washington's effort as to 'overthrow' aims to negatively present its role in Syria, as the word means 'to remove someone by force'.

As far as the Compassion move is concerned, RT expresses concern for the number of casualties that have fallen due to the 'civil war' that has been going on for a long period of time ('The UN special peace envoy to Syria has urged the international community to take advice from Russia to resolve the four-year-long civil war that has claimed 210,000 lives and left 1.5 million Syrians with injuries and disabilities'). That is to say, RT and Russia are concerned that if the war continues more lives may be lost, i.e., RT and Russia sympathise with the victims of this 'revolution'.

In terms of the strategy of Apparent Altruism, the report shows that Russia is willing to help Syria and that it is ready to do whatever possible in this regard ('Russia has used its veto on 
three occasions since the outbreak of the conflict to prevent the UN Security Council from taking punitive actions against Bashar Assad'). Russia is shown as the unselfish saviour of the Syrian crisis.

Negative Comparison is also present in this report. It talks about Syria as a 'hotbed for international terrorism' which refers to the 'rebels' fighters ('Syria has meanwhile turned into a hotbed for international terrorism'). Such comparison has an aim of emphasizing the negative image of the out-group, since RT considers this to be the result of the actions of the 'rebels'.

As far as the strategy of Generalization is concerned, the report generalizes the dogma of 'extremism' on all the members of the out-group, i.e., the opposition ('The area has turned into a global training ground for extremists'). Thus, RT invests in the negative presentation of the others.

The strategy of Concretization is used in this report too. As part of the process of emphasising the negative image of the out-group, RT describes in concrete terms the facts about the 'radical groups' ('Experts told UN Security Council in March that up to 22,000 foreign fighters from around 100 countries went to Syria and Iraq to join various radical groups').

As for the strategy of Warning, the report emphasises the idea that Syria has attracted foreign fighters to the degree that it has become a 'hotbed' for the extremist groups from around the world ('Assad's government has been long sounding the alarm, saying foreign fighters were increasingly present among the rebel forces for years'). Referring to the situation as such aims to warn the others that the consequences will not be pleasant if the current situation continuous. Hence, the report implicitly warns against the opposition or the 'rebels' who attract those foreign fighters.

The strategy of Presupposition is used twice in this report to refer to the out-group. First, The RT reports from Assad that 'to halt the ongoing armed conflict in Syria countries like Turkey, Saudi Arabia, Qatar, and some European states should first and foremost stop arming the terrorists' which presupposes that those countries already 'arm' the terrorists. Second, the report mentions that 'neighbors like Turkey chose to turn a blind eye to the stream of extremists traveling across the border' which also has a presupposition: Turkey supports the extremists.

\section{2 Report 2}

The report's headline is 'Crisis, what crisis?-The al-Qaeda takeover of Syria'. The headline is formed in a question form, which obviously denies and mocks the idea of the existence of a crisis. It instead refers to what is going on in Syria as prepared by al-Qaeda to control Syria.

In terms of the strategy of Negative Lexicalisation, the report uses the term 'al-Qaeda affiliated rebels' to propose negative connotations of the 'rebels' ('This weekend it was reported that al-Qaeda affiliated rebels were "almost completely in control" of the last major government held city in the Idlib province in northern Syria'). Al-Qaeda is a notorious terrorist group. Hence, the connection between those who claim to be peaceful with al-Qaeda 
aim is to conclude that those 'rebels' are also terrorists.

Moreover, the report uses negative lexical items when it refers to the 'West' as well (In fact, the lack of concern regarding the militants'gains in Syria exposes the fundamental deceit at the heart of Western foreign policy. The elites claim to be fighting radical Islamists, yet in Syria they're doing everything they possibly can to ensure that the side that's fighting radical Islamists, the secular Syrian government, is weakened and eventually defeated'). RT refers to this double standard way of dealing as 'deceit' which means a 'behaviour that is meant to fool or trick someone'. Thus, the West, including those who want the removal of Assad, do not have noble aims because the Assad's government is the 'only side that is fighting the terrorists in Syria', yet, they want him to be defeated.

In terms of Hyperbole, RT exaggerates in reporting the news item ('Syrian government's coastal heartlands including the important port of Latakia, a Baathist stronghold are under direct threat. It's a major advance for the cause of al-Qaeda, yet what is most revealing is the lack of reaction or any concern from Western leaders'). That is to say, the West does not care whether a terrorist group or any other party that takes control as long as the current Syrian government is removed.

The Compassion move is also utilised in this report, as the report shows sympathy towards the victim 'the Druze man' of the out-group ('A Syrian Druze man who posted information online which detailed Israel's co-operation with the Nusra Front was arrested in the Israeli-occupied Golan Heights earlier this year').

In terms of Negative Comparison, the report says that the West's war on terror is a 'phony war' ('Last month, Syria's President Assad drew attention to the West's phony war against ISIS. He noted that there were only about 10 raids a day from the coalition of "rich and advanced" countries against the Islamic State'). The word 'phony' means 'not real, true or genuine, intended to make someone think something that is not true', thus, the West is deceiving the world by this behaviour according to RT. Making such a comparison aims to present the out-group in a negative frame.

Generalisation strategy is utilised in this report to paint the actions of the West with a negative intention that is contradictory to what they says ('In fact, the lack of concern regarding the militants'gains in Syria exposes the fundamental deceit at the heart of Western foreign policy'). Accordingly, their intentions are different than what is apparent or said, since the latter is referred to as a deceitful entity.

In terms of Concretization, the report emphasises the West's negative actions in Syria in order to present a tangible image of what the latter does and how it is different from the declared purpose ('The elites claim to be fighting radical Islamists, yet in Syria they're doing everything they possibly can to ensure that the side that's fighting radical Islamists, the secular Syrian government, is weakened and eventually defeated').

Regarding Norm and Value Violation strategy, the report indicates that what the West is doing in Syria is 'deceit'. According to the rational human beliefs and values, deception is a terrible act that every human being should avoid because it leaves negative consequences and hurts 
the other. Therefore, the West breaks this norm by saying that their aim is to defeat terrorism, while their intentions are different.

As far as Presupposition is concerned, the report presupposes negative objectives about the out-group. For instance, 'You'd think that Western leaders would be alarmed at the al-Qaeda advances given how much they warn us of the "threat" from radical Islamists and how many Western troops were lost in the "war on terror" in Afghanistan' presupposes that since the 'Western leaders' are not alarmed by al-Qaeda's advance in Syria despite the fact that it is a terroristic group. Hence, their claims to fight terrorism are not real.

\subsection{Report 3}

The headline of the report is 'Syrian refugees in Lebanon fear fleeing unrest again, may head to Europe'. The gist of the report is that the unrest in Syria has led many people to flee their homes to Lebanon and other areas. That is to say, those who started the violence in Syria by making protests are the reason why those refugees are now in danger.

In terms of the strategy of Negative Lexicalisation, the headline of the report refers to the action of the refugees as 'fleeing' which means 'to run away from danger or evil'. Hence the report refers to the Syrian situation as 'evil', and those refugees are escaping it after they had been settling there peacefully before the protests.

Regarding Hyperbole, the use of the word 'burden' to refer to how the Lebanese government feels towards the Syrian refugees has a hyperbolic sense ('Over 1.2 million Syrians are estimated to be in Lebanon. But according to some estimates, the figure is as high as 2 million - and more continue to arrive, RT's Paula Slier says. And for the country of 4.5 million, millions of refugees are an unaffordable burden'). The report aims to show that those refugees suffered in Syria and now suffer in Lebanon because of the so-called revolution initiated by groups supported by the West. Therefore, whatever the consequences, the West is to blame for the sufferings that those immigrants go through.

As for the Compassion Move, the report shows that RT is very concerned about those refugees who have fled their home because of the 'turmoil ('Most of the migrants crossing into the EU through Macedonia and Serbia are refugees escaping unrest in Syria. But the largest number of refugees found shelter in Turkey and Lebanon; And as Slier discovered in eastern Lebanon, many of the refugees feel they might have to flee yet again and move further').

Regarding Negative Comparison, the report talks about the bad situation of the refugees in Lebanon and raises fears that it could be similar to that of Syria ('Many fear the Syrian scenario may repeat there and they will have to flee again'). In RT's view, the blame lies on 'rebels' who are supported by the West. After all, it is the West that is to blame for this negative 'scenario'.

In terms of Concretization, the report expresses in concrete terms the hardship that the refugees go through in Lebanon, which is caused by the riots in Syria ('Sure we are afraid the Syrian scenario will be repeated in Lebanon because it started in Syria in the same way," 
Syrian refugee Kamal Ahmed told RT." It was easy to come to Lebanon from Syria but if something similar to Syria will happen here, where will we go? We are afraid." ). Thus, RT implies that those refugees are victims of the protests that took place in Syria and caused people to run away.

The report also uses the strategy of Warning to alarm the powers in charge to take action. Thus, it talks about the number of Syrian refugees and the dangers that could cost them the most precious thing they have ('The European asylum seeker crisis is intensifying, as hundreds of thousands of people from Middle East and North Africa try to get to European shores at any cost, sometimes paying for it with their lives').

The strategy of Norm and Value Violation is also used in this report to refer to the struggle of the refugees in finding a safe place to settle in. RT implicitly refers to the idea that all those struggles are caused by the riots in Syria in the first place. Thus, the negative consequences of those protests cast their shadow on the innocent people, which breaks the human values and norms ('More than a million Syrian refugees feel unwelcome guests in Lebanon, where anti-government protests are only worsening').

\subsection{Report 4}

The general meaning of this report may be assumed through its headline, which says 'Strategic depopulation' of Syria likely cause of EU refugee crisis - Assange'. Thus, RT, through this report tackles two issues: One is that there is a planned act of emptying Syria of its people, and the second is that this plan backfired and caused the European refugee crisis.

In terms of Negative Lexicalisation, the report talks about 'countless waves of refugees' and 'strategic depopulation' as plans made by the 'opponents' of the Syrian regime ('The flooding of Europe by countless waves of refugees may be the result of the "strategic depopulation" of Syria carried out by opponents of the country's government').

Regarding Hyperbole, exaggerated terms are used in this report. For example, referring to the refugee crisis as a 'strategic depopulation' refers to the negative acts of the out-group, and thus presents it in a negative image.

Compassion Move is another strategy exploited in this report. The reports draws the attention back to Assad, indicating that despite the continuous attempts by Assad to 'fight terrorism' the West still underestimates them ('Meanwhile any of Assad's attempts to battle terrorism and the expansion of Islamic State (IS, formerly ISIS) strength were presented as a demonstration of weakness and "an example of [the] Syrian government not having full control over its territory to encourage the government overthrow,"'). Hence, RT is concerned about the Syrian president and shows that he is being fought for whatever he does, whether it was good or bad. In other words, he is a victim of the West's policies.

As for the Apparent Altruism move, the report mentions that Russia is the selfless side in this war whose aim is to fight 'terrorists' and settle peace ('In late September, Russia began airstrikes against the terrorists in Syria at the request of President Bashar Assad, allowing government forces to launch a large-scale offensive and recognize a turning point in the 
conflict.').

As far as the strategy of Negative Comparison is concerned, the report makes use of it to refer to a similar case in which there was a 'strategic depopulation' and also made by the West ('Syria isn't the only case of migration being used as a weapon in recent history; during the Iraq War, Sweden told the US that "the acceptance of Iraqi refugees was part of its contribution," according to cables'). That is to say, this is a common strategy by the West in its endeavor to overthrow regimes.

In terms of Generalisation, the report mentions that all the negative acts and the bloodshed in Syria is caused by the interference of the U.S. ('US interference has to Syria being ensnared in a bloody conflict since 2011. Over 220,000 people have been killed, according to UN estimates. Government forces have fought various militant groups throughout the conflict, including the so-called moderate opposition backed by the West as well as the jihadist IS and Jabhat al-Nusra terror groups').

As far as the strategy of Concretization, the report expresses in detail the negative acts of the West in an attempt to present them in an undesirable way ('Of course, the CIA perceives they have a benefit. They create a problem and then they're given a greater budget to clean the problem up. Similarly, with the contractors, arms dealers and arms manufacturers. If there's no problem then their budgets are cut. So they create problems, " Assange explained'). Such a description of the out-group is enough to create a negative mental model in the viewer's minds.

Norm and Value Violation move is utilised in this report to add to their negative description. For, saying that certain groups create those polar wars to benefit financially is a scandalous and shameful act that not an ordinary rational individual accepts (" only particular factions that pushed for it" might believe that they will benefit in the end').

In terms of Presupposition, the report indicates that the 'strategic depopulation' is 'carried out by the opponents of country's government' presupposes the responsibility of the U.S. and its allies, they oppose the Syrian regime.

\subsection{Report 5}

This report has the headline '2015-The year Russia exposed Western Barbarism'. The of the overall meaning of the report aims to provide a number of events (listed as sub-headlines in the structure of the report) which are intended to prove how Russia 'exposed Western Barbarism'.

In terms of the Negative Lexicalisation strategy, RT uses the adjective 'barbaric' to describe the 'Western powers' ('2015 was the year Russia exposed the barbaric nature of Western powers, from their criminal conspiracy for regime change in Syria, to aggression against Yemen, Iran, Russia, China and any country that does not toe the line'). The word 'barbaric' means 'very rude, offensive, not polite or proper, and very cruel'. Not only that, the report also accuses the West of making a 'criminal conspiracy' which means 'a secret plan made by two or more to do something that is harmful'. In other words, RT says that the West conspired 
to change the regime in Syria. The word 'aggression' means a 'hostile action against another country' which RT uses to talk about the Western action in Yemen, Iran, Russia, China and anyone else who does not abide by the Western rules.

The Compassion move is utilised to show sympathy towards the victims of the out-group. For instance, the report talks about the Yemeni people, e.g. ('thousands of Yemeni civilians have been slaughtered by US-supported bombardment on residential areas lasting nine months and counting'). This functions as an emphasiser of the negative image of the U.S. and its allies who victimise and kill innocents.

In terms of Hyperbole, the report emphasises the negative acts of the others using exaggerated description in an attempt to negatively present the out-group ('The emergence of billionaire property magnate Donald Trump as US presidential contender marks the full outward degeneration of American politics, whereby demagoguery, racism and fascism have entered into mainstream public discourse. This is while US police violence against African-Americans and other minorities reaches epidemic proportions').

As far as the Compassion Move is concerned, the report criticises the European Union and the West in general for not providing the necessary needs for the refugees. The report talks about the mechanism in which the refugees cross the seas using 'rickety boats' ('Take the European Union's immigration crisis. Up to one million refugees have been recorded entering EU borders this year, according to the United Nations. Thousands perished while crossing the Mediterranean and Aegean Seas on rickety boats to reach the shores of Italy or Greece'). The word 'rickety' means 'not strong or stable and likely to break'. Hence, the lives of those refugees who are the victims of the West's policies are on the line, yet, Europe does not do anything about the case. Worse still, some European countries do not accept those refugees in the time where other European countries are 'overwhelmed' with refugees ('Countries such as Britain and France were accused of not doing enough to take in refugees, while "front line" states Greece, Hungary, Croatia and Slovenia complain they are being overwhelmed by the influx'). Therefore, RT feels sympathy for the Syrian refuges who are victims of the West's policies in Syria.

Apparent Altruism is also used in the report to refer to the positive role of the in-group and negative role of the out-group. Thus, RT talks about how Russia's and other friendly sides intervention in Syria is 'legal' ('Russia's military intervention in the Syrian conflict in support of its long-time ally beginning on September 30 has transformed the dynamic. Russia's intervention, along with that of Iran and Lebanon's Hezbollah resistance movement, is the only lawful foreign contingency in the five-year-old war, because it has been requested and approved by the Syrian government'). As Such, presenting the self as altruist aims to present of positively framing the in-group, while the American intervention in Syria is considered by RT as merely invasion, since it is illegal.

As far as Negative Comparison is concerned, RT explicitly and directly compares the West to 'barbarism' ('Seventy years after the defeat of fascism in Europe, once again the battle against barbarism, rogue states and state-sponsored terrorism is very much extant today. And once again, it is Russia that is holding the line against all-out descent into international 
barbarism.'). Hence, the West is represented as a bunch of savages, and the credit goes to Russia for 'exposing' this 'Western 'barbarism savagery'.

The report also uses the strategy of Generalization to indicate that the presence of all foreign forces in Syria is illegal, except that of Russia and other allies ('All other foreign interventions in Syria from the United States and EU members, Britain, France and Germany, are in violation of international law'). By doing so, RT puts the out-group in the circle of law breakers, and thus, they are the bad side in this conflict.

As for the strategy of Concretization, the report vividly concretises the actions of the out-group in terms of the Syrian crisis ('Thus, in a very real way, the EU has fueled the conflict in Syria by aiding and abetting illegally armed militants, which has boomeranged into the worst refugee crisis since the Second World War - a crisis that is straining the very existence of the EU'). Therefore, visualising the role of the EU as such offers an image for the viewer's minds of what exactly the EU does in Syria.

In terms of Norm and Value Violation, the report emphasises the illegal and abnormal acts of the out-group. For instance, the report talks about Washington's aim to 'illegally' change the regime in Syria ('the US and its allies are accused of not being fully committed to combating terrorist groups in Syria, because these militants are at the same time being used by Washington and its partners as proxy forces to illegally achieve regime change in Syria'). Hence, RT draws the out-group as an entity that seeks to achieve its aims regardless of any appreciated norms and values that humans hold dear.

As for the strategy of Presupposition, the report focuses on presenting the out-group in a deformed image, especially when it says that 'President Obama may say the US welcomes "the peaceful rise of China". But all the indications are that the US is doing everything to antagonize Beijing and to thwart its perceived global power status' which presupposes that Obama is a hypocrite.

\subsection{Report 6}

The report's headline is 'Hypocritical much? Merkel blames Russia for Syrian's plight' which focuses on presenting that Europe, not Russia, is responsible for the Syrian crisis.

In terms of Negative Lexicalisation, the report uses words with negative connotations to refer to the out-group's actions ('April 22 becomes the deadliest unrest to date, with 75 people killed in clashes with security forces'). The word 'deadliest' confirms that the clashes broke out as a result of the protestors' commencement of fire. . Similarly, the word 'bloody confrontation' ('Both the EU and the US impose sanctions on Assad and his inner circle for the first time in an attempt to stop the bloody confrontation between the government and the opposition') functions as a confirmation of the aggressive nature of the protestors.

In terms of Hyperbole, RT presents the initial Syrian protests against the government as preparations for a certain kind of war ('Activists across Syria gear up for what they call the 'Great Friday' protest, hoping that it will become the largest anti-government rally'). This is implied by the use of terms such as 'gear up' which symbolises those who started the protests 
as soldiers getting packed for a war.

As for the Compassion move, the report shows the Syrian people as victims of the 'Wahhabists' ( 'So now Chancellor Merkel is worried about Syrian civilians and the hardships of war! Was she asleep under a rock for the past five years, or did she somehow confuse her support for 'moderate' Wahhabists in Syria and Iraq as an act of mercy for those communities living under the boot of Terror's black flag?').

As far as the Apparent Altruism move is concerned, the report puts Russia in the place of the helper and saviour that comes from abroad to solve problems ('Russia's arrival into the Syrian fray blew this play completely out of the water - exposing those realities Western powers have been so keen to keep under wrap for the sake of political decorum'). Hence, Russia is there for a noble purpose which is to reveal the enmity and hidden bad intentions of the West. Moreover, Russia's goal is real as compared to the West's ('Russia is actually bombing ISIS positions as opposed to Washington "selective” targeting').

Apparent Honesty is also used in this report. For RT shows that it tells the truth about the refugees issue ('there is indeed a refugee issue: Syrians are indeed running... anyone remotely in tune with world affairs will tell you that much'). The report also mentions that it is a rational thing ('The fact is, the Syrians are running away from war. Anyone in their right mind would in fact run in the face of danger; this is not a political statement, simply a human observation'). Therefore, RT disclaims any negative statements about its group regarding the issue of refugee, as the danger which caused them to flee was made by the regime's opposition.

In terms of Negative Comparison, RT compares the German counselor Angela Merkel to a person who is 'sleeping under a rock' in order to show that she is hypocritical. The report says that Merkel only cares about refugees in order to make some political gains. Moreover, the report resembles Merkel to an 'echo chamber' ('Merkel is clearly serving as an echo chamber to Saudi Arabia and Turkey's anger, frustration, and-let's just say it -fear in the face of Damascus' advances against Islamic State forces').

As far as Concretization is concerned, the report concretises the actions of the West ('flipped the narrative away from Western military interventionism and its de facto support of terror as a weapon of political mass-destabilization when he attempting to shift blame back onto Syrian President Bashar'). That is, RT states explicitly in order to visualise it for the viewers to create a negative mental model.

In terms of Presupposition, the metaphorical question 'Was she asleep under a rock for the past five years' presupposes that Merkel's statements are hypocritical and that she has negative intentions because she remained silent from the beginning of the crisis, but now she speaks for a personal purpose.

\section{Results of Analysis}

This section shows the results of the Ideological Discourse Analysis. In other words, it presents the kinds of discursive strategies used in the reports published by RT to cover the 


\section{Macrothink}

Syrian crisis. Moreover, it also shows the difference between the RT's reports before and after the Russian military involvement in Syria.

To begin with, RT polarises between the in-group and out-group, especially when it comes to discussing the Syrian crisis. RT represents the policy of Russian government, thus, it deals with all the opponents of this policy as the out-group. Hence, the U.S, Europe, and their allies are often represented negatively in the Syrian crisis reports.

In terms of the use of the discursive strategies, RT uses eleven strategies in most of its reports, namely, Negative Lexicalisation, Hyperbole, Compassion Move, Apparent Altruism, Apparent Honesty, Negative Comparison, Generalisation, Concretisation, Warning, Norm and Value Violation, and Presupposition. Alliteration was not found in RT's reports.

Regarding the difference between the reports published before and after the Russian military moved to Syria, RT made a shift in focus. Before the Russian intervention, RT focused on the refugees' humanitarian crisis with a few times in which the U.S. is mentioned. However, after the Russian involvement, RT turned its compass towards the U.S.

Table 1. Frequency of occurrence of the refugees and the U.S. in RT's reports before Russia's involvement

\begin{tabular}{llllll}
\hline Report No. & Report1 & Report 2 & Report 3 & & \\
\hline Month & April 13 & April 27 & Sep & Total & Per \\
Refugees & 0 & 0 & 11 & 11 & $\mathbf{6 8 . 7 \%}$ \\
U.S & 3 & 2 & 0 & 5 & $31.2 \%$ \\
\hline
\end{tabular}

Table 1 shows that before the Russian involvement, RT was focused on presenting issue of the Syrian refugees which received a total occurrence (11) times only on September corresponding to $(68 \%)$ of the overall occurrence. On the other hand, the U.S. received less attention with a total occurrence of (5) times which corresponds to (31.2\%), divided into (3) times on April 13, and (2) times on April 27. 


\section{Macrothink}

Table 2. Frequency of occurrence of the refugees and the U.S. in RT's reports after Russia's involvement

\begin{tabular}{llllll}
\hline Report No. & Report 4 & Report 5 & Report 6 & & \\
\hline Month & Oct. & Dec. & Feb. 2016 & Total & Per \\
Refugees & 5 & 4 & 4 & 13 & $27 \%$ \\
US & 6 & 25 & 4 & 35 & $72.9 \%$ \\
\hline
\end{tabular}

Table 2 shows a drastic change in RT's attention regarding the presentation of the Syrian crisis. The table shows that after the Russian military came to Syria, RT turned its compass from the refugees to talk about the U.S which received an overall occurrence (35) times which corresponds to (72.9\%), divided into (6) times on October, (25) on December, and (4) on February 2016. The refugees received less attention with a total of frequency (27) times, corresponding to (27\%), divided into (5) on October, (4) on December, and (4) on February 2016. Fig. (1) Below illustrates this variation in detail.

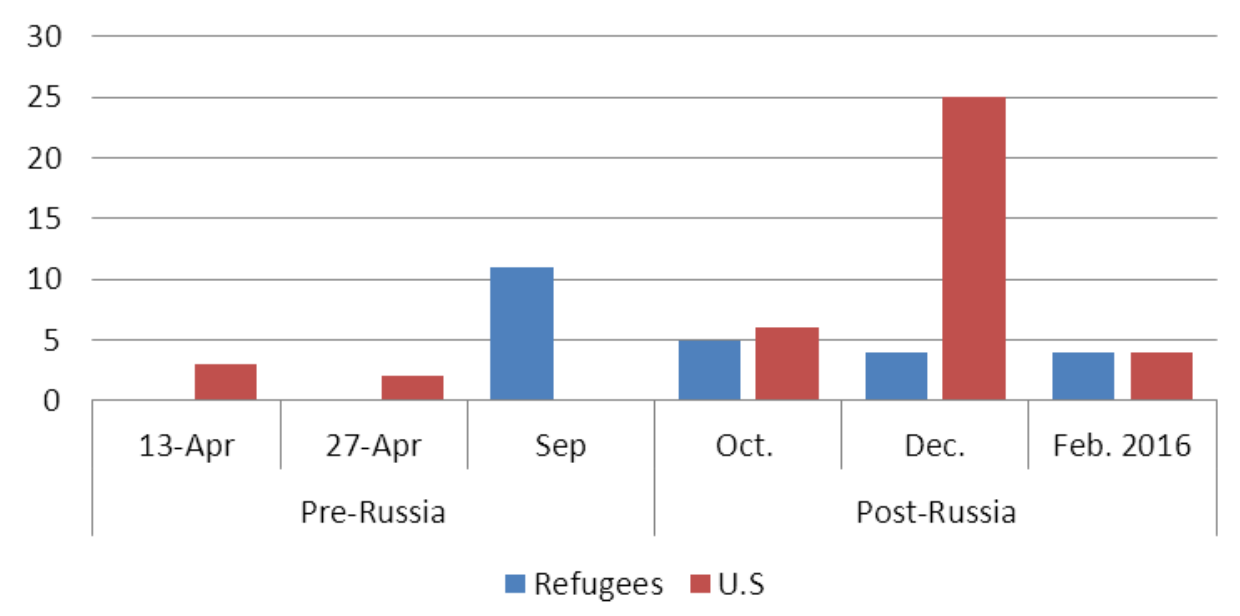

Figure 1. Distribution of occurrence of the Refugees and the U.S. in RT's reports, before and after Russia's involvement

\section{Conclusion}

The language used in RT's presentation of the Syrian crisis is manipulated by adhering to a number of discursive strategies which serve to either to positively present the self, or negatively present the other.

There is a polarisation between the in-group and out-group in terms of reporting the Syrian crisis on RT. The negative acts of the others are emphasised by using discursive strategies 
such as Negative Lexicalisation, Hyperbole, Negative Comparison, Generalisation, Concretisation, Warning, Norm and Value Violation, and Presupposition. Whereas the positive acts of the self are emphasized by using strategies like Compassion move and Apparent Altruism, and Apparent Honesty.

The positive acts of the U.S. and the negative acts of Russia are either mitigated or hidden.

RT shows the out-group (the U.S.A) as more dominant and powerful than the in-group (the regime and its supporters). This is used in order to authorize the acts of the channel's in-group regardless of any negative consequences.

Before Russia's intervention, RT's reports were mainly focused on the refugees, but after the Russian military involvement, RT focused on negatively presenting the role that the U.S. played in Syria. That is to say, Russia is there to counteract the 'negative' American acts.

\section{References}

Ali, S., \& Kazemian, B. (2015). Critical Discourse Analysis of a Reading Text 'Pakistan and the Modern World': A Speech by Liaquat Ali Khan. Communication and Linguistics Studies, $1(3), 35-41$.

Ali, S., Kazemian, B., \& Bughio, F. A. (2015). An investigation of the reading text 'Pakistan Analysis of the Last Address of the Holy Prophet (PBUH). International Journal of Language and Linguistics. Special Issue: Critical Discourse Analysis, Rhetoric, and Grammatical Metaphor in Political and Advertisement Discourses, 4(1-1), 1-9.

Cap, P., \& Okulska, U. (Eds.). (2013). Analyzing genres in political communication: theory and practice (Vol. 50). John Benjamins Publishing. https://doi.org/10.1075/dapsac.50

Crystal, D. (2008). A dictionary of linguistics and phonetics. Oxford: Blackwell. https://doi.org/10.1002/9781444302776

Fairclough, N. (1989). Language and power. London: Longman.

Fairclough, N. (1992). Discourse and Social Change. Cambridge: Polity Press. https://doi.org/10.1177/0957926592003002008

Fairclough, N. (1995). Critical Discourse Analysis: The Critical Study of Language. London: Longman

Fairclough, N., \& Wodak, R. (1997). Critical Discourse Analysis: A Multidisciplinary Introduction. London: Sage Publications.

Hammersley, M. (1997). On the foundations of critical discourse analysis. Language and Communication, 17, 237-248. https://doi.org/10.1016/S0271-5309(97)00013-X

Holmes, J. (2005). Power and Discourse at Work. In M Lzar (ed.) 'Feminist Critical Discourse Analysis’ (pp. 31-60). Basingstoke: Palgrave. https://doi.org/10.1057/9780230599901_2

Jorgenson, M., \& Philips, L. (2002). Discourse Analysis as Theory and Method. London: 
Sage Publications. https://doi.org/10.4135/9781849208871

Kazemian, B., \& Hashemi, S. (2014a). Nominalizations in scientific and political genres: A systemic functional linguistics perspective. International Journal of Humanities and Social Sciences, 3(2), 211-228.

Kazemian, B., \& Hashemi, S. (2014b). Critical discourse analysis of Barack Obama's 2012 speeches: Views from systemic functional linguistics and rhetoric. Theory and Practice in Language Studies (TPLS), 4(6), 1178-1187. https://doi.org/10.4304/tpls.4.6.1178-1187

Kazemian, B., \& Hashemi, S. (2017). A Radical Shift to a Profound and Rigorous Investigation in Political Discourse: An Integrated Approach. International Journal of English Linguistics, 7(3), 115-128. https://doi.org/10.5539/ijel.v7n3p115

Kazemian, B., Behnam, B., \& Ghafoori, N. (2013). Ideational grammatical metaphor in scientific texts: a Hallidayan perspective. International Journal of Linguistics, 4(4), 146-168. https://doi.org/10.5296/ijl.v5i4.4192

Luke, A. (2002). Beyond Science and Ideology Critique: Developments in critical discourse analysis. Annual Review of Applied Linguistics. https://doi.org/10.1017/S0267190502000053

Noor, M., Ali, M., Muhabat, F., \& Kazemian, B. (2015). Systemic Functional Linguistics Mood.

Rogers, R. (2005). Critical Discourse Analysis in Education. Lawrence Erlbaum Associates: Publishers Mahwah, New Jersey. London.

Schiffirin, D., Tannen,, D., \& Hamilton, H. (2001). The Handbook of Discourse Analysis. Blackwell.

Thomas, L. (2004). Language, Society and Power. Routledge.

Thompson, J. B. (1990). Ideology and Modern Culture. Cambridge: Polity Press.

Van Dijk, T. A. (1995b). Discourse Analysis as Ideology Analysis. In A. Wenden, \& C. Schaffner (Eds.), Language and Peace in Press. Dartmouth: Aldershot. van Dijk, T. A. (1998) Ideology: A Multidisciplinary Approach. London: Sage.

Van Dijk, T. A. (1997). Gender and discourse. London; Thousand Oaks, Calif.: Sage Publications.

Van Dijk, T. A. (1998). Critical Discourse Analysis. In D. Tannen, D. Schiffrin, \& H. Hamilton. Handbook of Discourse Analysis. Massachusetts: Blackwell.

Van Dijk, T. A. (1993). Principles of Critical Discourse Analysis. Discourse and Society, 4(2), 243-289. https://doi.org/10.1177/0957926593004002001

Wodak, R., \& Meyer, M. (2001). Methods of Critical Discourse Analysis. London: Sage Publications. https://doi.org/10.4135/9780857028020 
Wodak, R., \& Meyer, M. (2009). Critical Discourse Analysis: History, Agenda, Theory, and Methodology. In R. Wodak, \& M. Meyer. (2001.), Methods of Critical Discourse Analysis. 2nd revised ed. London: Sage. pp. 1-33. https://doi.org/10.1080/17405900903180954

Wodak, R. (1995). Critical linguistics and critical discourse analysis. In J. Verschueren (Ed.), Handbook of pragmatic. Amsterdam: Benjamins. https://doi.org/10.1075/hop.m.cri1

Zhou, Q., \& Kazemian, B. (2015). A Rhetorical Identification Analysis of English Political Public Speaking: John F. Kennedy's Inaugural Address. International Journal of Language and Linguistics. Special Issue: Critical Discourse Analysis, Rhetoric, and Grammatical Metaphor in Political and Advertisement Discourses. 4(1-1), 10-16.

Zindabad' (Long Live Pakistan): Critical discourse analysis perspective. Education and Linguistics Research, 1(2), 42-51.

\section{Web Sources}

Al-Jazeera (2017). Syria's civil war explained from the beginning. http://www.aljazeera.com/news/2016/05/syria-civil-war-explained-160505084119966.html

www.rt.com

\section{Appendix: Full News Reports by RT}

\section{Report 1}

\section{UN envoy to Syria tells world to listen to Russia to end civil war}

Published time: 13 Apr, 2015 13:13Edited time: 13 Apr, 2015 14:22

The UN special peace envoy to Syria has urged the international community to take advice from Russia to resolve the four-year-long civil war that has claimed 210,000 lives and left 1.5 million Syrians with injuries and disabilities.

"Russia has influence on Damascus, and it's very important that they get involved," Staffan de Mistura, who was challenged by the UN Secretary-General Ban Ki-moon last Thursday to relaunch the failed political peace process in Syria, told The Independent.

"The two countries' relationship goes back to the time when Bashar al-Assad's father was in power. Therefore the Russians do have a knowledge of the system and the way they think, " the Swedish-Italian diplomat said.

The civil war in Syria began in 2011, when the US-backed opposition began an armed rebellion against President Bashar Assad's government during the Arab Spring. By 2013, large portions of eastern Syria and western Iraq had fallen under control of militants from the Islamic State in Iraq and Syria (ISIS/ISIL, now known as Islamic State). While declaring the need to fight ISIS, Washington has continued to demand the overthrow of Assad in favor of" moderate opposition."

The US has been supporting the Syrian rebels, who insist that the Syrian president should be 
ousted. Meanwhile, Russia has used its veto on three occasions since the outbreak of the conflict to prevent the UN Security Council from taking punitive actions against Bashar Assad. In January, Russia and the US held the Geneva-2 peace talks between Assad's government and the Syrian opposition. No agreement was reached after two rounds of negotiations, however.

Last September, the US-led coalition started airstrikes in Syria as a part of a joint effort to battle Islamic State militants, who had seized large swathes of land in north Syria and Iraq. Assad repeatedly pointed out that strikes are an illegal intervention, saying they are unauthorized by a UN Security Council resolution and thus violate the sovereignty of Syria.

The Syrian president told Russian media in late March that the West does not have a political solution to the crisis in Syria, and claimed it is only interested in destroying his government.

"They want to turn us into puppets. I do not think that the West has a political solution. It does not want one. When I say the West, I am primarily referring to the US, France, the UK. Other countries are secondary," Mr Assad stated, adding that to halt the ongoing armed conflict in Syria countries like Turkey, Saudi Arabia, Qatar, and some European states should first and foremost stop arming the terrorists. He told journalists that the Syrian Air Force, which is relatively small in comparison to the US-led coalition, conducts in a single day many times the number of the airstrikes conducted by a coalition that includes 60 countries. "This doesn't make sense. This shows the lack of seriousness," Syria's president said. "They don't want to get rid of ISIS completely, " he added.

Syria has meanwhile turned into a hotbed for international terrorism. Assad's government has been long sounding the alarm, saying foreign fighters were increasingly present among the rebel forces for years, but neighbors like Turkey chose to turn a blind eye to the stream of extremists traveling across the border.

Experts told UN Security Council in March that up to 22,000 foreign fighters from around 100 countries went to Syria and Iraq to join various radical groups. The area has turned into a global training ground for extremists. "For the thousands of [foreign fighters] who traveled to the Syrian Arab Republic and Iraq ... they live and work in a veritable international finishing school'for extremists as it was in the case in Afghanistan during the 1990s," the experts wrote in their report, Reuters reported.

Staffan de Mistura told RT in March that it would be far easier to address the issue of ISIS in Syria if the opposition and the government negotiated a ceasefire.

"Every conflict needs to start with some type of discussion, among the Syrian people in this particular case. We have a new factor which is called Daesh/ISIS. And I'm sure I believe that this is certainly increasing the urgency of addressing the conflict in Syria. Daesh has been taking advantage of the fact that there is a weak environment in Syria and a conflict which has been going on for the last four years," he said.

\section{Report 2}

\section{Crisis, what crisis? -The al-Qaeda takeover of Syria}

Neil Clark is a journalist, writer, broadcaster and blogger. He has written for many 
newspapers and magazines in the UK and other countries including The Guardian, Morning Star, Daily and Sunday Express, Mail on Sunday, Daily Mail, Daily Telegraph, New Statesman, The Spectator, The Week, and The American Conservative. He is a regular pundit on RT and has also appeared on BBC TV and radio, Sky News, Press TV and the Voice of Russia. He is the co-founder of the Campaign For Public Ownership @PublicOwnership. His award winning blog can be found at www.neilclark66.blogspot.com. He tweets on politics and world affairs@NeilClark66

Published time: 27 Apr, 2015 16:40Edited time: 27 Apr, 2015 16:42

This weekend it was reported that al-Qaeda affiliated rebels were "almost completely in control" of the last major government held city in the Idlib province in northern Syria.

This is really big news as it means that the Syrian government's coastal heartlands including the important port of Latakia, a Baathist stronghold are under direct threat. It's a major advance for the cause of al-Qaeda, yet what is most revealing is the lack of reaction or any concern from Western leaders.

You'd think that Western leaders would be alarmed at the al-Qaeda advances given how much they warn us of the "threat" from radical Islamists and how many Western troops were lost in the "war on terror" in Afghanistan.

In fact, the lack of concern regarding the militants' gains in Syria exposes the fundamental deceit at the heart of Western foreign policy. The elites claim to be fighting radical Islamists, yet in Syria they're doing everything they possibly can to ensure that the side that's fighting radical Islamists, the secular Syrian government, is weakened and eventually defeated.

Last month, Syria's President Assad drew attention to the West's phony war against ISIS. He noted that there were only about 10 raids a day from the coalition of "rich and advanced" countries against the Islamic State. "The Syrian air force, which is very small in comparison with this coalition, conducts in a single day, many times the number of air strikes conducted by a coalition which includes sixty countries. This doesn't make sense. This shows the lack of seriousness...there is no serious effort to defeat terrorism, " Assad said.

Far from trying to defeat terrorism - the West and its regional allies have been supporting it.

Israel, the country which we're repeatedly told by its cheerleaders in the West, is in the "front line" of the "war on terror" has been acting as al-Qaeda's de facto ally in Syria. It's made at least ten bombing raids on the country since 2012- but tellingly, not a single one up to now has been directed at the radical Islamists fighting Assad's forces - all have been on Syrian government/army targets or on groups fighting with the Syrian army against the terrorists such as January's attack, which killed a senior Iranian general and six Hezbollah fighters. (Today, news broke that another Israeli air strike had killed "four militants" on the Israel/Syria border - but we don't know which groups the 'militants' belong to.)

In March, it was reported that Israel had opened its borders with Syria to provide medical treatment to wounded al-Qaeda and al-Qaeda affiliated Nusra Front soldiers and after treating them, released them straight back over the Syrian border to continue their fight against a 
secular government which protects Christians and other religious minorities.

The help that the IDF (Israeli Defense Forces) has given to Syrian rebels at the Golan Heights has been documentedin a series of UN reports.

Israel clearly doesn't want its activities in Syria to be subject to too much scrutiny.

A Syrian Druze man who posted information online which detailed Israel's co-operation with the Nusra Front was arrested in the Israeli-occupied Golan Heights earlier this year.

Needless to say, no "Je Suis Sidqi al-Maqt" campaign has yet been launched by self-righteous "anti-censorship" free speech crusaders in the west. As the media monitoring organization Media Lens has observed:"There's no Je Suis Charlie when it comes to scrutiny of Israel".

There's no \#JeSuisCharlie when it comes to scrutiny of \#Israel.http://t.co/TQQ8M5ogQT\#Palestine\#Gaza@PSCupdateshttps://t.co/gVn7jOi477

— Media Lens (@medialens) April 27,2015

"Now it seems that Israel is in direct alliance with al-Qaeda in Syria, "writes Asa Winstanley, in Middle East Monitor. "This is a tactical alliance, meant purely to bleed the country and prolong the civil war."

The de facto Israeli/al-Qaeda alliance gets very little - if any publicity in the West - we've seen no real debate in our "open" and "democratic" societies on why our great "ally" is helping people we're regularly told are our most deadly enemies. Instead pro-Israel neocons and faux-leftists, masquerading once again as concerned "humanitarians" who care passionately about the Syrian people, propagandize for the imposition of "no-fly zones" knowing that this will greatly weaken the ability of the Syrian government to defend their country - a Syrian government which they desperately want toppled not because of its human rights record- but because of its alliance with Iran and Hezbollah.

Of course, Israel is not the only major Middle Eastern power which is gunning for Assad. Saudi Arabia has long called for his overthrow and seems to have stepped up its support for anti-Assad forces since the beginning of the year and the accession of King Salman to the throne. Writing in the neocon Washington Post, Liz Sly puts the latest"rebel gains" in Syria down to the role played by the Saudis and its regional allies.

Weapons that the West supplied to the so-called "moderate rebels" have - surprise, surprise fallen into the hands of the al-Qaeda affiliates. In March, Britain's Daily Mail newspaper showed photographs of Nusra Front fighters posing with US missiles they had captured from "western-backed rebels."

"Al Qaeda groups taking over Syria cities with advanced US weapons supplied to the 'moderates' If you think this wasn't planned, think again," tweets Syria-based analyst and activist Edward Dark.

Al Qaeda groups taking over \#Syria cities with advanced U.S weapons supplied to the "moderates"..if u think this wasn't planned, think again_Edward Dark (@edwardedark) April 


\section{5,2015}

Assad's imminent demise has been wrongly called many times before-mainly by neocons that couldn't wait to see the back of him. But the latest al-Qaeda advances are deeply worrying and unless the situation on the ground changes quite quickly, then the days of the secular government in Damascus could be numbered.

The extremists would have got there already, if the British Parliament had voted to bomb Syria in 2013, as the neocons wished. "If David Cameron had got his way, the jihadis could be in control of Damascus by now" the former British Ambassador to Syria, Peter Ford, wrote in a blistering attack on British government policy towards Syria in The Guardian. "To call for the overthrow of the secular Syrian government, to demonize it out of all proportion, to predict its imminent fall, as Cameron and (Foreign Secretary) Hague were doing in 2012 and 2013, - and then to wail that it was nothing to do with them when British Muslims set off to hasten said overthrow - is inconsistent and non-sensensical", the Ambassador declared.

The approach is indeed "inconsistent" and "non-sensensical" if one takes at face value the Western elite's claims to be implacably opposed to al-Qaeda. But of course, they are not implacably opposed. If the Western leaders like Cameron did genuinely want to check al-Qaeda's advances then clearly the logical step would be to work alongside the authorities in Damascus and not against them which is what they're actually doing.

The fact that they don't seem the least bit concerned about the recent gains made by al-Qaeda and its affiliates in Syria tells us once again, that it's not Islamist radicals that the West is most concerned about defeating but secular, independently-minded governments which don't kowtow to the endless war lobby.

The statements, views and opinions expressed in this column are solely those of the author and do not necessarily represent those of RT.

\section{Report 3}

\section{Syrian refugees in Lebanon fear fleeing unrest again, may head to Europe}

Published time: 3 Sep, 2015 13:37

More than a million Syrian refugees feel unwelcome guests in Lebanon, where anti-government protests are only worsening. Many fear the Syrian scenario may repeat there and they will have to flee again.

Most of the migrants crossing into the EU through Macedonia and Serbia are refugees escaping unrest in Syria. But the largest number of refugees found shelter in Turkey and Lebanon.

Over 1.2 million Syrians are estimated to be in Lebanon. But according to some estimates, the figure is as high as 2 million - and more continue to arrive, RT's Paula Slier says. And for the country of 4.5 million, millions of refugees are an unaffordable burden.

The Syrian refugee crisis in Lebanon is getting worse by the day. Aid is being slashed and now the ongoing anti-government protests in the capital Beirut are making the destabilized situation 
there increasingly uncertain.

Lebanon's capital has been gripped by anti-government protests for days. Tens of thousands of people hit the streets of Beirut, demanding the resignation of Environment Minister Mohammad Machnouk. As part of the 'You Stink' campaign, protesters expressed anger at government corruption and a lack of basic services, including power and water, and demanded government action.

And as Slier discovered in eastern Lebanon, many of the refugees feel they might have to flee yet again and move further. With many of the Middle East and North African countries being in turmoil, displaced persons from Syria have little options to be picking from.

"Sure we are afraid the Syrian scenario will be repeated in Lebanon because it started in Syria in the same way," Syrian refugee Kamal Ahmed told RT. "It was easy to come to Lebanon from Syria but if something similar to Syria will happen here, where will we go? We are afraid."

The European asylum seeker crisis is intensifying, as hundreds of thousands of people from Middle East and North Africa try to get to European shores at any cost, sometimes paying for it with their lives.

Statistics from the International Organization for Migration (IOM) confirmed the current global asylum seeker crisis marks the biggest flow of people across the world since 1948.

According to the IOM's research, over 234,770 asylum seekers have landed in Greece since January 2015, 114,276 arrived in Italy and thousands more have landed in Spain and Malta. This compares with 219,000 who arrived in the whole of Europe in 2014.

The refugee camp visited by RT crew is just an hour-and-a-half's drive from Beirut. Most of the refugees living there have come from the Syrian city of Homs and the East Huta. The Lebanese authorities refuse to call this place a 'camp,' because it could become a long-term fixture, like Palestinian camps in the country. And the tensions between the Lebanese population and the coming Syrians are only growing.

"Last winter was very cold and tough and the tents fell on us because of the wind and huge amount of snow. It is a very bad life - if the same situation happens here like in Syria, there will be chaos, "Syrian refugee Fahim Rashidjamul told RT. "What will happen to the Lebanese people is the same that happened to us. They will suffer the same fate."

\section{Report 4}

\section{'Strategic depopulation' of Syria likely cause of EU refugee crisis - Assange}

Published time: 27 Oct, 2015 02:13Edited time: 27 Oct, 2015 09:20

The flooding of Europe by countless waves of refugees may be the result of the "strategic depopulation" of Syria carried out by opponents of the country's government, WikiLeaks founder Julian Assange has suggested.

Transparency organization WikiLeaks has looked through its diplomatic cables and 
unearthed "an interesting speculation about the refugee movement," Assange said in an interview with Geek news site, ThePressProject.

"So, the speculation was this: Occasionally opponents of a country would engage in strategic depopulation, which is to decrease the fighting capacity of a government, " he explained.

The whistleblower pointed out that "it's predominantly the middle class that is fleeing" Syria on account of having "language skills, money, some connections." Engineers, managers and civil servants are "precisely, the classes that ...[are] needed to keep the government functioning," he said.

Syrian people are encouraged to flee their country "by Germany saying they'll accept many-many refugees, and by Turkey taking nearly three million refugees, thus significantly weakening the Syrian government," Assange stressed.

Syria isn't the only case of migration being used as a weapon in recent history; during the Iraq War, Sweden told the US that "the acceptance of Iraqi refugees was part of its contribution," according to cables.

The WikiLeaks founder said that it's a "disgrace" that the US refuses to take in Syrian refuges because it's Washington who should be held accountable for the hundreds of thousands of people arriving in Europe and making EU states close its borders with one other.

"The situation comes about as a result of the US, UK and French policy in the Middle East together with the behavior of US regional allies in the Middle East-Qatar, Turkey, Jordan and Israel... and Saudi Arabia, " he said.

The intercepted documents, already published by WikiLeaks, revealed that the US had been plotting to overthrow the Syrian government since around 2006, Assange stressed.

"It was trying to make the Syrian government 'paranoid' trying to get it to 'overreact' by instilling that fear and paranoia; trying to make it worried about coups; trying to stir up sectarian tensions between Sunnis and Shias ... trying to stop foreign investment in Syria and secretly funding a variety of NGOs in Syria also to make trouble, using the Saudis and Egypt to help push that along," he said.

Meanwhile any of Assad's attempts to battle terrorism and the expansion of Islamic State (IS, formerly ISIS) strength were presented as a demonstration of weakness and "an example of [the] Syrian government not having full control over its territory to encourage the government overthrow," the whistleblower added.

Assange stressed that the people in America have nothing to gain from the Syrian conflict, but "only particular factions that pushed for it" might believe that they will benefit in the end.

"Of course, the CIA perceives they have a benefit. They create a problem and then they're given a greater budget to clean the problem up. Similarly, with the contractors, arms dealers and arms manufacturers. If there's no problem then their budgets are cut. So they create problems, " Assange explained. 
By meddling with Syria, Washington also pursued "a grand area strategy to weaken Hezbollah, to allow Israel greater control of Golan Heights, maybe a buffer zone as well; to knockout (Syria) a regional ally of Iran; to knockout the last Russian base that's left outside the former Soviet Union in Tartus; to create a path for a gas pipe that is proposed pass is from Qatar to Saudi and up through Syria to Europe, which will compete with Russian gas, " added Assange.

US interference has to Syria being ensnared in a bloody conflict since 2011. Over 220,000 people have been killed, according to UN estimates. Government forces have fought various militant groups throughout the conflict, including the so-called moderate opposition backed by the West as well as the jihadist IS and Jabhat al-Nusra terror groups.

In late September, Russia began airstrikes against the terrorists in Syria at the request of President Bashar Assad, allowing government forces to launch a large-scale offensive and recognize a turning point in the conflict.

\section{Report 5}

\section{5 - The year Russia exposed Western barbarism}

Finian Cunningham (born 1963) has written extensively on international affairs, with articles published in several languages. Originally from Belfast, Ireland, he is a Master's graduate in Agricultural Chemistry and worked as a scientific editor for the Royal Society of Chemistry, Cambridge, England, before pursuing a career in newspaper journalism. For over 20 years he worked as an editor and writer in major news media organizations, including The Mirror, Irish Times and Independent. Now a freelance journalist based in East Africa, his columns appear on RT, Sputnik, Strategic Culture Foundation and Press TV.

Published time: 27 Dec, 2015 16:00

2015 was the year Russia exposed the barbaric nature of Western powers, from their criminal conspiracy for regime change in Syria, to aggression against Yemen, Iran, Russia, China and any country that does not toe the line.

It is a thread we can find in many other stories, many of which were covered by Western media. The difference is the latter media omit or lose the all-important thread of how Western powers have created or exacerbated major, pressing international problems.

\section{Crisis made by the EU}

Take the European Union's immigration crisis. Up to one million refugees have been recorded entering EU borders this year, according to the United Nations. Thousands perished while crossing the Mediterranean and Aegean Seas on rickety boats to reach the shores of Italy or Greece. EU nations held several top-level summits on the emergency, but no collective response was forthcoming, leading to much recrimination between the 28-member states. Countries such as Britain and France were accused of not doing enough to take in refugees, while "front line" states Greece, Hungary, Croatia and Slovenia complain they are being overwhelmed by the influx. 
Internal EU tensions have threatened to unravel the founding principles of the bloc, such as the free movement of citizens under the Schengen Agreement. Germany, under Chancellor Angela Merkel, has emerged as the most generous of EU states, taking in the largest numbers of asylum seekers. However, Merkel's ruling Christian Democrat party has incurred a backlash from anti-immigrant groups. Elsewhere Europe has seen the rise of right-wing, anti-immigrant and anti-EU political parties, from the National Front in France to the United Kingdom Independence Party (UKIP) in Britain. Similar gains for ultra-nationalists have been made in Denmark, the Netherlands and Belgium.

The bitter irony of the EU immigration crisis and its pressure on the foundations of the bloc is that most of the would-be immigrants have come from war-torn Syria. As astute observers published by RT and other alternative media, but censored out of the Western media - have noted, the conflict in Syria precipitating the refugee crisis has come about from unlawful interference in the Arab country by the EU. Britain and France have given military support to an insurgency against the elected government of President Bashar al-Assad, along with support from the US and its regional allies, Turkey, Saudi Arabia and Qatar.

\section{Heresy of truth: Terrorist blowback}

Most of the insurgent groups in Syria are in fact comprised of foreign mercenaries espousing radical Islamist ideologies, associated with internationally designated terrorist groups, such as Al-Qaeda and the so-called Islamic State (IS, formerly ISIS/ISIL). The latter claimed the massacre in Paris on November 13, when some 130 people were killed in gun and bomb attacks. But to say "blowback" in the Western media is tantamount to outrageous thought-crime. It is verboten.

The EU has previously sanctioned the Syrian government, saying it is responsible for the violence in the country. In 2014, Brussels aided the insurgency by lifting an embargo on oil exports from Syrian areas under the control of anti-government militants, whose dominant faction is the IS terror group. Thus, in a very real way, the EU has fueled the conflict in Syria by aiding and abetting illegally armed militants, which has boomeranged into the worst refugee crisis since the Second World War - a crisis that is straining the very existence of the EU.

\section{Russia's game changer}

Russia's military intervention in the Syrian conflict in support of its long-time ally beginning on September 30 has transformed the dynamic. Russia's intervention, along with that of Iran and Lebanon's Hezbollah resistance movement, is the only lawful foreign contingency in the five-year-old war, because it has been requested and approved by the Syrian government.

All other foreign interventions in Syria from the United States and EU members, Britain, France and Germany, are in violation of international law. Russia's intense aerial bombardment against all illegally armed militants, including the IS and Al Nusra Front, is not encumbered with the false dichotomy articulated by the US-led military coalition, which disingenuously divides militants into extremists and moderates. In three months of Russian aerial operations, the losses suffered by anti-government militants in Syria have been much greater than during 16 months of bombing by the US-led coalition. That is because Russia is working in close 
liaison with the Syrian Arab Army, which is now making sweeping ground advances. Also, the US and its allies are accused of not being fully committed to combating terrorist groups in Syria, because these militants are at the same time being used by Washington and its partners as proxy forces to illegally achieve regime change in Syria.

The US, Britain and France have reportedly supplied weapons to so-called "moderate rebels" only for these weapons and indeed fighters to end up with the known extremist brigades of IS and Al Nusra. Saudi Arabia and Qatar have also funded Islamist networks, such as Jaish al Fatah and Ahrar al Shams, which are known to be involved with IS and Al Nusra.

\section{Oil smugglers are us}

Russia's dramatic intervention in Syria has exposed what can only be described as a charade in which the US, European powers and their regional allies have been involved in trying to destroy a sovereign country through covertly supporting an array of illegally armed mercenary networks.

A central part of the charade is how NATO member and EU aspirant Turkey has been involved in smuggling oil and weapons across the Syrian border. Russia's concerted airstrikes have exposed the Turkish connection to the Western-backed illegal regime-change operation in Syria, and no doubt that was a factor in why Turkish fighter jets shot down a Russian warplane on November 24.

\section{Trump and the American descent into fascism}

There were several other significant developments this year. The emergence of billionaire property magnate Donald Trump as US presidential contender marks the full outward degeneration of American politics, whereby demagoguery, racism and fascism have entered into mainstream public discourse. This is while US police violence against African-Americans and other minorities reaches epidemic proportions; and federal state powers of surveillance and arrest continued to erode civil rights.

\section{US-backed aggression in Yemen}

A foreign war of aggression on Yemen by a US-backed military coalition of Saudi Arabia and other Gulf Arab states demonstrated a descent into lawlessness, where the United Nations appears more impotent than ever to uphold international law. Thousands of Yemeni civilians have been slaughtered by US-supported bombardment on residential areas lasting nine months and counting, yet Western media have largely overlooked those crimes, focusing instead on allegations of violations against civilians by Russian warplanes in Syria.

\section{Nuclear deal with Iran... based on fake allegations}

The conclusion in July of the P5+1 nuclear deal between Iran and the world powers was hailed as a triumph of diplomacy by US President Barack Obama. Of lesser note in the Western media 
was the decision by the UN nuclear watchdog, the IAEA, to terminate its 10-year investigation into alleged Iranian nuclear weapons development. The IAEA said it had concluded there was no evidence of any Iranian activity to build a nuclear bomb. That means 10 years of Western claims against Iran have been trumped-up and the rationale for crippling Western-imposed economic sanctions on Iran is likewise null and void. So when are Washington and its European allies going to compensate Iran with billions of dollars for damage inflicted for no legal reason on its economy and nation's health?

\section{US provocation towards China}

With so much apparently going in the news, the tensions between the US and China have probably not received the attention deserved. Nevertheless, these tensions are truly alarming. The US has made several provocative military intrusions on China's territorial claims in the South China Sea, the latest one being a B-52 bomber that "accidentally" made a flyover. It is noteworthy that the US aggression came only weeks and months after China's President Xi Jinping made his first-ever state visit to the US earlier this year. President Obama may say the US welcomes "the peaceful rise of China". But all the indications are that the US is doing everything to antagonize Beijing and to thwart its perceived global power status.

This year, the US Pentagon nominated China and Russia as primary "national security threats". This is while the US ratchets up gratuitous tensions with both countries in the South China Sea and through NATO expansion around Russian territory. NATO's enlisting of former Soviet country Montenegro in the Balkans as its newest member is further testimony to the relentless expansion of the US-led military alliance since the end of the Cold War nearly 25 years ago - in flagrant contradiction of past agreements with Moscow not to let NATO encroach on Russian interests.

\section{Putin speaks truth to power}

Yet the year ends with the US and its European allies slapping more economic sanctions on Russia over alleged infringements in Ukraine, when conflict in the latter country is clearly, and provably, a result of the kind of Western interference that Putin highlighted at the UN.

Putin made a seminal speech at the UN General Assembly in September when he clearly called out rogue powers who have trashed international law with illegal military, political and economic interventions overseas. The deterioration of legal standards, sovereignty and explosion of conflicts and terrorism in many parts of the world can be directly attributed to the machinations of the United States and its European partners. "Do you see now what you have done?" asked Putin before the UN.

\section{0 years on, Russia still leads the battle against barbarism}

The year 2015 marked the 70th anniversary of the end of the Second World War, when Nazism and European fascism was defeated mainly through the military might and sacrifices of the Soviet Union. Notably - and appropriately in a profoundly true sense - the commemorations held in Moscow to mark that epic victory against fascism were not attended by the political leaders from the US, Britain, France and other European countries, owing to their alleged 
disputes with Russia over Ukraine.

Seventy years after the defeat of fascism in Europe, once again the battle against barbarism, rogue states and state-sponsored terrorism is very much extant today. And once again, it is Russia that is holding the line against all-out descent into international barbarism.

\section{Report 6}

\section{Hypocritical much? Merkel blames Russia for Syria's plight}

Catherine Shakdam is a political analyst, writer and commentator for the Middle East with a special focus on radical movements and Yemen. A regular pundit on RT and other networks her work has appeared in major publications: MintPress, the Foreign Policy Journal, Mehr News and many others.Director of Programs at the Shafaqna Institute for Middle Eastern Studies, Catherine is also the co-founder of Veritas Consulting. She is the author of Arabia's Rising - Under The Banner Of The First Imam

Published time: 9 Feb, 2016 13:53

While Western powers and their ME allies made clear they do not support Russia's play in Syria since it upsets their own political ambitions, the latest round of propaganda takes the game of geopolitics to the Land of Oz.

German Chancellor Angela Merkel is leading the neocon pack down the little yellow brick road, throwing outrage and words of condemnation on what she describes as the unbearable suffering of civilian populations in Syria.

Well, that's nice... if only her words were not so completely hypocritical and - I would personally add - revolting political posturing.

So now Chancellor Merkel is worried about Syrian civilians and the hardships of war! Was she asleep under a rock for the past five years, or did she somehow confuse her support for 'moderate' Wahhabists in Syria and Iraq as an act of mercy for those communities living under the boot of Terror's black flag? Interesting how war refugees and the welfare of civilians are conveniently rationalized for very politically motivated attacks against Russia, Iran, and all those non-aligned powers, which have systematically denounced Western imperialism and covert interventionism.

“We're not only shocked, but also outraged, at what's happened in terms of human suffering in the past few days for tens of thousands of people through bomb attacks, including attacks above all from Russia," Merkel told reporters in Ankara this Monday on the side-line of a meeting with Turkish Prime Minister Ahmet Davutoglu.

Merkel is clearly serving as an echo chamber to Saudi Arabia and Turkey's anger, frustration, and - let's just say it - fear in the face of Damascus' advances against Islamic State forces. Remember that when it comes to Syria, regime change remains the Western powers' foremost priority - by their own admission. In October 2014, John Kerry, the US secretary of state, said there would never be peace in Syria "while Assad remains the focus of power." 
In January 2015, Kerry also flipped the narrative away from Western military interventionism and its de facto support of terror as a weapon of political mass-destabilization when he attempting to shift blame back onto Syrian President Bashar al-Assad, noting: "It is time for President Assad, the Assad regime, to put their people first and to think about the consequences of their actions, which are attracting more and more terrorists to Syria, basically because of their efforts to remove Assad."

If this approach worked in early 2015, Russia's arrival into the Syrian fray blew this play completely out of the water - exposing those realities Western powers have been so keen to keep under wrap for the sake of political decorum: mainly the terror profiteering and funding extra-curricular activities of its allies.

It was US Senator Dick Black, who, in an interview with RT, blew the whistle on those shady alliances the US and other Western capitals have entertained by noting: "I believe that Saudi Arabia and Turkey are the two greatest dangers to world peace... It is Saudi Arabia, through the Wahhabist doctrine, which is spreading terrorism across the globe. It's not Iran, it's not Syria or any other country."

Senator Black is certainly not alone in his views.

"No one has a particularly credible long term strategy [for the Middle East] because it would involve facing some very uncomfortable truths - about the nature of the fight ahead of us, and imperfections of one of our most important allies in the Middle East," said US Senator Chris Murphy in a speech at the Council on Foreign Relations in New York this January, while alluding to Riyadh's alliances with terror group across the Greater Middle East.

As for Turkey and Saudi Arabia, losing ground to the rising pan-Arab resistance movement is frightening!

But let's circle back to Merkel's allegations and Davutoglu's genocide cries. "We are going to work together to end the suffering of the Syrian people under these barbaric acts... No one can justify or tolerate Russian air strikes which amount to an ethnic massacre."

Coming from the lips of a Turkish official, and in the light of Turkey's abysmal human rights abuses against its Kurdish communities, this comment really takes the cake.

Here is my question: What ethnic massacre? How deluded must Turkey be at this stage in the game to even suggest ethnic cleansing, when its military and security services are currently carrying out a brutal and murderous crackdown in its southern region against the Kurds?

If Turkey today is suddenly waving the refugee card to generate political sympathies, it is because it stands to lose a very lucrative black market: oil, weapons, human trafficking, now that Russia is actually bombing ISIS positions as opposed to Washington "selective" targeting.

Allow me to address Merkel's concerns though, because there is indeed a refugee issue: Syrians are indeed running... anyone remotely in tune with world affairs will tell you that much. But Russia is certainly not to blame.

The fact is, the Syrians are running away from war. Anyone in their right mind would in fact 


\section{Macrothink \\ Education and Linguistics Research \\ ISSN 2377-1356 \\ 2017, Vol. 3, No. 2}

run in the face of danger; this is not a political statement, simply a human observation. In fact, the Syrians have been running for the past five years - sometimes within their own borders, sometimes without. Today their escape is grabbing headlines because they have headed north towards Europe, and this has become a major issue for Western capitals - or perhaps an excellent excuse to further strip civil liberties and increase government oversight of the public sphere.

At the end of the day, this refugee plight was brought about by Western powers and their regional allies. Russia is merely working to clean up the mess and end Terror's reign in Syria on the express invitation of its president.

Another point which needs to be made. Russia is not targeting civilians; it is in fact targeting ISIS positions near Aleppo, offering air cover as Syrian troops crackdown on those terror pockets.

"No evidence has yet been provided on alleged casualties as a result of Russian airstrikes in Syria, Kremlin spokesman Dmitry Peskov said Tuesday, quickly adding: "In regard to Chancellor Merkel's claims of alleged casualties in Russian airstrikes in Syria, one needs to take into account that regardless of the huge number of similar statements, someone has yet to produce a single shred of evidence that would make this information trustworthy."

The real question we all should be asking is: Why in the world are we still allowing our officials to lie and manipulate their way to heights of power?

\section{Copyright Disclaimer}

Copyright reserved by the author(s).

This article is an open-access article distributed under the terms and conditions of the Creative Commons Attribution license (http://creativecommons.org/licenses/by/3.0/). 